\title{
The Impact of Working Capital Management on Firm Profitability: A Comparison Between Seasonal and Non-Seasonal Businesses
}

\author{
Ahmed Chand \\ Department of Commerce and Finance, Superior University, Lahore, Pakistan \\ Sadaf Akram* \\ Department of Business Administration, Government College Women University, Faisalabad, Pakistan \\ Hamza Akram \\ Department of Aviation Management, University of Sialkot, Sialkot, Pakistan \\ Ayesha Murad \\ Department of Economics, Superior University, Lahore, Pakistan \\ Luqman Kareem \\ Department of Commerce and Finance, Superior University, Lahore, Pakistan
}

The research is financed by Asian Development Bank. No. 2006-A171(Sponsoring information)

\section{Abstract}

The study examines the impact of working capital management (cash conversion cycle) on firm profitability and provides a comparison between seasonal and non-seasonal businesses of Pakistan by using the time period of 5 years (2013-2018). The study finds a negative impact of working capital management on firm profitability. Moreover, the study finds no difference between seasonal and non-seasonal businesses in terms of working capital management and firm profitability. The study suggests reducing the length of cash conversion cycle to increase profitability.

Keywords: Return on Asset, Working Capital Management, Profitability, Earnings per share

DOI: $10.7176 /$ RJFA/10-15-02

Publication date: August $31^{\text {st }} 2019$

\section{Introduction}

Working capital management upsets a firm's profitability and risk is generally recognized and received considerable attention. Smith (1980) Short term financial health \& Company's operational efficiency is measure by working capital (lan le et al.,) Working capital means the current assets of the organization that can be change from one type to other kind among everyday activities of the firm (Gitman,2002). Capital management is widely re-explored by the researchers accompanying by capital budgeting, (lizaridis and teryfonidis, 2016). It is important for the firm as blood for the life (Reddy and Patkar, 2004). Profitability of the firm is vigorously affected by the way it is tried to managed its working capital (deloof, 2003) WC has a great influenced on firm's profitability so that it should managed in that way that the profit of firm will be maximized (deloof, 2003) and there is strong connotation between management of working capital and the profitability of firm (Azhar and Noriza, 2010; Mathuva, 2010; Alipour, 2011)). It received huge attention because the risk and profitability of firm is influenced by the management of working capital. firm faces high risk and return when it creates aggressive working capital policy (means to say that when firm invest low amount in working capital), although firm faces low risk and return when it has conservative working capital policy (means to say when firm invest high amount in working capital ) (caballero, teruel and solano, 2011). And a firm is essential towards the maintenance of balance between working capital and profitability while conducting its day to day operation. We found many investigations on the management of working capital and the profitability of firm in different parts of the world (Jose et al., 1996; Shin and Soenen, 1998; Wang, 2002; Deloof, 2003; Garcia-Teruel and Martinez-Solano, 2007; lan le et al., 2018; shubita, 2013; quayyum, 2011; among others); even in Pakistan (khalid et al.,2018; shah and khan, 2018; Muhammad, jan and ullah, 2012; raheman et al., raheman and nasar, 2007; makuri et al., among others) had tests linear relations among investment in working capital and firm's performance; results of such studies shows that the profitability will be higher if the we invest more money in working capital.

However, unlike the previous studies, the purpose of our study is to analyze the impact of working capital management on firm profitability and provides a comparison between seasonal and non-seasonal businesses of Pakistan. This study contributes to the literature in such a way that no any study is found in Pakistan which compare the relationship of WCM and profitability of firm in Pakistan." 
The remaining paper is organized as follows: section two explains the review of previous literature and development of hypothesis, section three presents the data and research methodology, section four describes the empirical results and discussions, section five provides the conclusion and paper ends with some future direction and limitations.

\section{Literature Review}

Khalid et al. (2018) studied the "influence of working capital management on the profitability of Pakistani electrical equipment firms detailed in KSE via cross sectional data from (2007-2012) and make that working capital management has a positive significant impact on the profitability of the firms by using regression analysis, linearity and normality tests.

Qayum (2011) examine the relationship among "working capital management and profitability in the principal of manufacturing organizations in Bangladesh by using the sample of panel data of four industries listed in Dhaka stock exchange from (2005-2009), by Using the test of regression analysis method this study establish that except food industry there is a significant relationship among profitability indicators and several working capital components of all industries and the significance level of relationship diverge from industry to industry.

Makori, jagongo (2013) examine the "effect of working capital management (WCM) on firm's profitability in Kenya through the sample of panel data of five manufacturing firms listed in Nairobi securities exchange from (2003-2012). This study establishes by using Pearson's correlation and ordinary least square (OLS) regression analysis techniques that all the variables have positive and significant association with firm's profitability although cash conversion cycle and number of day's receivable had negative relationship with firm's profitability.

Javid (2014) examined the "relationship among working capital management and performance in accounting and market valuation in the point of view of SME's listed in Karachi stock exchange by testing the sample of panel data of 54 SME's from (2006-2010) through panel data regression analysis. This study found that indicators of working capital management had an apparent outcome on performance of firms but the cash conversion cycle and net trading cycle had no any effect on profitability.

Raheman et al. (2010) studied the effect of working capital management of Pakistani manufacturing firms on their profitability by using sample of balanced longitudinal data of 204 firms listed in Karachi stock exchange (KSE) from (1998-2007). Pearson's correlation and longitudinal data analysis were applied to test the relationship, and the study found that the CCC, NTC and Inventory turnover in days had negative relationship with firm performance. This study suggests that efficient management of working capital \& financing will increase firm's profitability.

Yonus et al. (2018) study the "effect of working capital management on the profitability, measured by return on asset (ROA) and Tobins Q (TQ) of firm listed in Bursa Malaysia by using the sample of panel data of 803 companies from (2010-2014) through regression analysis and therefore the findings illustrate that number of sales inventory days (DSI), the number of account receivable days (DSO) has negative Impact on firm's profitability. This study suggests that if firm wants to be more profitable than it should sell its inventory quickly, and accelerate in collecting debt from customers.

Mumtaz et al. (2011) inspect the influence of "working capital management on progressing market's firm performance in Pakistan by using the sample of 22 chemical sector firms listed in KSE from (2005-2010) through regression. results of this study indicate that there is negative relationship between working capital management and firm performance and also the size of firm is positively affected by the profitability of firm in other words the relation among firm size and profitability is positive.

Raheman, and nasar. (2007) examined the "impression of different measures of working capital management on net operating profitability of Pakistani firms by using the sample of panel data of 94 firms listed in KSE from (1999-2004) through Pearson's correlation and regression analysis and the result indicates that strong negative relation of variables of working capital management on firm's profitability and there is positive relationship between FS and its profitability.

Akoto, vitor \& angmor (2013) analyze the "relationship between working capital management and profitability of manufacturing firms by using different measures of working capital and the sample of panel data of 13 firms listed in ghana from (2005-2009) through panel data analysis, and therefore the result indicates that except the accounts receivable days, the measures of working capital have positive influence on profitability of firms. This study suggests that firm's manager can produce worth for its shareholder by making incentives to reduce their accounts receivable to 30 days.

Lan le et al (2018) inspect the impact of working capital management on public firm's financial performance by using the Longitudinal data of 69 firms listed in Ho Chi Minh Stock Exchange (HOSE) from (2014-2016) through regression analysis and therefore the result indicates that working Capital Management positively influence the financial performance of firms in the sample.

"Caballero, García-Teruel and Martínez-Solano (2014) explored the interdependence among working capital management and corporate performance and analyzed whether the optimal level of working capital is responsive 
to surrogate dimension of financial constraints by using the sample of non-financial UK companies through quadratic model and the result indicates that an upended U-shaped relation between investment in working capital and firm performance and the optimal level of working capital is lower for the firms which are expected to be financially constrained.

Afeef (2011) analyze the effect of working capital management on profitability of SME's listed in KSE by using the sample of 40 firms from (2003-2008) by using different indicators of working capital management therefore the findings of the study indicate that there are observable effects of different indicators of working capital management on the profitability of SME's.

\subsection{Development of Hypotheses}

On the basis of above literature, the following hypotheses are constructed:

$\mathrm{H}_{1}$ : There is a negative impact of working capital management on firm profitability.

\section{Data and Methodology}

The present study attempts to investigate the effect of working capital management on firm profitability and provides a comparison between seasonal and non-seasonal businesses of Pakistan. The research is conducted on sugar sector (seasonal) and textile sector (non-seasonal). The firms which fulfill all the characteristics of the study are chosen as sample. A total of 50 firms (25 firms from sugar and 25 firms from textile sector) are selected as sample. The data cover the period of 2013 to 2018. The data are gathered from annual published financial reports of sampled firms.

\subsection{Variables Description}

The study uses firm profitability as dependent variable and working capital management as independent variable. Firm size and debt ratio are used as control variables. Firm profitability is measured by two ways: (ROA) which is the ratio of net income to total assets and EPS which is the ratio of net income to numbers of shares outstanding. Working capital management is measured by cash conversion cycle (CCC). CCC is calculated as Average Collection Period (ACP) + Inventory Turnover in Days (ITD) - Average Payment Period (APP); where ACP = $[\{(\mathrm{AR} 1 / 1+\mathrm{AR} 31 / 12) / 2\} / \mathrm{Sales}] * 360, \mathrm{ITD}=[\{(\mathrm{INV} 1 / 1+\mathrm{INV} 31 / 12) / 2\} / \mathrm{CGS}] * 360$ and $\mathrm{APP}=[\{(\mathrm{AP} 1 / 1+$ $\mathrm{AP} 31 / 12) / 2\} / \mathrm{CGS}] * 360$. Firm size of total assets is calculated by taking the natural logarithm \& debt ratio is the ratio of total debts to total assets.

\subsection{Econometric Model}

To analyze the impact of working capital management on firm profitability Multiple Regression Model are used. The empirical analysis has two steps, first for sugar sector and second for textile sector. The following equations are estimated separately for sugar and textile sector:

$$
\begin{aligned}
& \text { ROAit }=\beta 0+\beta 1(\text { CCCit })+\beta 2(\text { DRit })+\beta 3(\text { FSit })+e i t \\
& \text { EPSit }=\beta 0+\beta 1(\text { CCCit })+\beta 2(\text { DRit })+\beta 3(\text { FSit })+\text { eit }
\end{aligned}
$$

Where; the abbreviation ROA is return on assets, \& abbreviation of CCC is cash conversion cycle, DR is debt ratio and FS is firm size for firm ' $i$ ' and time' $t$ '. $\beta 0, \beta 1, \beta 2$, and $\beta 3$ are the coefficients and 'e' represents the error term.

\section{Results and Discussions}

Table 1 (see appendix) shows the "descriptive statistics of our variables. This table is divided into 2 sections the first section shows the descriptive about the seasonal sector of sugar, whereas second section shows the descriptive about the no-seasonal sector of textile, table indicates the mean, median and (SD) standard deviation of our variables moreover this table also shows the minimum and maximum values of our data.

Table 2 is representing the Pearson's correlation analysis, of our total variables used in this study. This table is also being divided into 2 section indicates the correlation of variables for the seasonal sector of sugar whereas the other portion of tables shows the correlation of variables for the non-seasonal sector of textile.

In the seasonal sector of sugar there is negative and significant correlation of CCC, FS and DR with ROA. CCC and EPS are also negatively correlated with each other, we found no any relation of FS and DR with EPS, also there is no any relation of FS and DR with CCC, on the other hand FS and DR also not related.

In the non-seasonal sector of sugar there is negative and significantly correlation of CCC, FS whereas positive correlation of DR with ROA. CCC also negatively related with EPS, whereas FS is positively related with EPS, DS do not correlate with EPS, whereas FS and DR also not correlated.

Table 3 (see appendix) shows the "regression analysis by using 2 dependent variables, that is ROA (for seasonal sugar sector), and EPS (for non-seasonal textile sector).

This table also consist of 2 section, In first section we are investigating the association between CCC on ROA, besides CCC we also use some control variables, the results indicates that all the variables are statistically 
significant except FS, specifically $\mathrm{C}$ is highly significant at $1 \%, \mathrm{CCC}$ and DR are significant at 5\% and we do not find any significant relation of DR with ROA.

In first section we are investigating the association between $\mathrm{CCC}$ on EPS, besides CCC we also use some control variables, the results indicates that all the variable are statistically significant, specifically $\mathrm{C}$ and $\mathrm{CCC}$ are highly significant at $1 \%$, DR are statistically significant at $5 \%$ and FS is significant at $10 \%$.

\section{Conclusions}

Company's operational efficiency and its short term financial health is measure by working capital (lan le et al.,) Working capital means the current assets of the organization that can be change from one type to other kind among everyday activities of the firm (Gitman,2002). Capital management is widely re-explored by the researchers accompanying by capital budgeting, (lizaridis and teryfonidis, 2016).

The purpose of our study is to analyze the impact of working capital management on firm profitability and provides a comparison between seasonal and non-seasonal businesses of Pakistan and the findings of this study indicates that in seasonal sector of sugar there is negative relation between CCC and ROA, on the other hand, in the nonseasonal sector of textile, there is negative relation among CCC and EPS, in other words we can say that, the profitability of firm is negatively related with WCM, which means that if want to increase firm's profitability, then we must reduce WCM, which indicates that on need to adapt aggressive WC policy, which means that one should invest lower amounts of money in WC so that the profitability of firm might increase.

\subsection{Limitations}

This study has some limitations. Firstly, this study takes only those firms that listed in KSE-100 index \& these are non-financial firms. Secondly, the focus of this study is only on non-financial firms. Thirdly, the sample size is small \& the time period of data is also small.

\subsection{Research Implications}

This study has some practical implication, as the result of this study shoes that CCC has negative impact on the profitability of firm so the firm should invest less money in cash conversion cycle. As our result tells that CCC has negative impact on ROA \& EPS. So, if firm wants to increase their returns, and earnings then they should adapt aggressive working policy which means that firm should invest low money in CCC that is WCM.

\section{References}

Akoto, R. K., Awunyo-Vitor, D., \& Angmor, P. L. (2013). Working capital management and profitability: Evidence from Ghanaian listed manufacturing firms.

Baños-Caballero, S., García-Teruel, P. J., \& Martínez-Solano, P. (2014). Working capital management, corporate performance, and financial constraints. Journal of Business Research, 67(3), 332-338.

Eljelly, A. M. (2004). Liquidity - profitability tradeoff: An empirical investigation in an emerging market. International journal of commerce and management, 14(2), 48-61.

Ismail, N., Khairani, N. S., Othman, A. A., Ismail, N., Ahmad, S. A., Ishak, I., ... \& Osman, S. UiTM Johor Online Journal.

Javid, S., \& Dalian, P. R. (2014). Effect of Working Capital Management on SME's Performance in Pakistan. European Journal of Business and Management, 6(12), 206-220.

Jose, M. L., Lancaster, C., \& Stevens, J. L. (1996). Corporate returns and cash conversion cycles. Journal of Economics and finance, 20(1), 33.

Juan García-Teruel, P., \& Martinez-Solano, P. (2007). Effects of working capital management on SME profitability. International Journal of managerial finance, 3(2), 164-177.

Khalid, R., Saif, T., Gondal, A. R., \& Sarfraz, H. (2018). Working Capital Management and Profitability. Mediterranean Journal of Basic and Applied Sciences (MJBAS), 2(2), 117-125.

Le, H. L., Vu, K. T., Du, N. K., \& Tran, M. D. (2018). Impact of working capital management on financial performance: The case of Vietnam. International Journal of Applied Economics, Finance and Accounting, $3(1), 15-20$.

Makori, D. M., \& Jagongo, A. (2013). Working capital management and firm profitability: Empirical evidence from manufacturing and construction firms listed on Nairobi securities exchange, Kenya. International Journal of Accounting and Taxation, 1(1), 1-14.

Mumtaz, A., Rehan, M., Rizwan, M., Murtaza, F., Jahanger, A., \& Khan, H. A. (2011). Impact of Working Capital Management on Firms' Performance; evidence from Chemical sector listed firms in KSE-100 Index. JOSR. Journal of Business and Management, 93-100.

Quayyum, S. T. (2011). Relation between working capital management and profitability in context of manufacturing industries in Bangladesh. International journal of Business and Management, 7(1), 58.

Raheman, A., \& Nasr, M. (2007). Working capital management and profitability-case of Pakistani firms. 
International review of business research papers, 3(1), 279-300.

Raheman, A., Afza, T., Qayyum, A., \& Bodla, M. A. (2010). Working capital management and corporate performance of manufacturing sector in Pakistan. International Research Journal of Finance and Economics, 47(1), 156-169.

Shin, H. H., \& Soenen, L. (1998). Efficiency of working capital management and corporate profitability. Financial practice and education, 8, 37-45.

\section{APPENDIX}

Table 1: Descriptive Statistics

\begin{tabular}{|l|l|l|l|l|l|l|l|l|l|l|}
\hline \multicolumn{5}{|c|}{ Sugar Sector (Seasonal) } & \multicolumn{5}{c|}{ Textile Sector (Non-Seasonal) } \\
\hline Variables & ROA & EPS & CCC & FS & DR & ROA & EPS & CCC & FS & DR \\
\hline Mean & 0.6517 & 0.0256 & 16.9736 & 20.7800 & 0.8326 & 1.0607 & 0.0070 & 24.2119 & 21.1904 & 1.6797 \\
\hline Median & 0.2339 & 0.1547 & 14.0787 & 21.7309 & 0.2658 & 0.1272 & 0.2148 & 19.1140 & 21.9527 & 0.1784 \\
\hline Maximum & 1.5065 & 1.1043 & 98.4014 & 24.3451 & 2.3146 & 1.7616 & 0.4764 & 102.5838 & 24.9433 & 2.8952 \\
\hline Minimum & -0.1250 & -0.2540 & 1.2487 & 6.3685 & -1.1587 & -0.1810 & -0.1441 & -3.0695 & 7.7586 & -1.4751 \\
\hline Std. Dev. & 3.6160 & 0.1229 & 6.6364 & 4.3779 & 3.0319 & 10.6526 & 0.0424 & 4.9678 & 4.0921 & 10.1539 \\
\hline
\end{tabular}

Table 2: Pearson Correlation Matrix

\begin{tabular}{|l|l|l|l|l|l|l|l|l|l|l|l|}
\hline \multicolumn{9}{|c|}{ Sugar Sector (Seasonal) } & \multicolumn{5}{c|}{ Textile Sector (Non-Seasonal) } \\
\hline Variables & ROA & EPS & CCC & FS & DR & Variables & ROA & EPS & CCC & FS & DR \\
\hline ROA & 1.0000 & & & & & ROA & 1.0000 & & \\
\hline EPS & $-0.0288^{*}$ & 1.0000 & & & & EPS & $-0.2155^{*}$ & 1.0000 & & \\
\hline CCC & $-0.0270^{*}$ & $-0.0511^{*}$ & 1.0000 & & & CCC & $-0.3190^{*}$ & $-0.0278^{*}$ & 1.0000 & \\
\hline FS & $-0.0040^{*}$ & 0.0253 & -0.1343 & 1.0000 & & FS & $-0.1887^{*}$ & $0.0556^{*}$ & $0.1078^{*}$ & 1.0000 \\
\hline DR & $-0.013^{*}$ & -0.0212 & 0.0363 & -0.1454 & 1.0000 & DR & $0.2571^{*}$ & -0.0778 & -0.0923 & -0.0791 & 1.0000 \\
\hline
\end{tabular}

Table 3: Regression Analysis

\begin{tabular}{|l|l|l|l|l|l|l|l|l|}
\hline \multirow{2}{*}{ Variables } & \multicolumn{4}{|c|}{ Sugar Sector (Seasonal) } & \multicolumn{3}{c|}{ Textile Sector (Non-Seasonal) } \\
\cline { 2 - 9 } & Coefficient & S. E & $\begin{array}{c}\text { t- } \\
\text { Statistic }\end{array}$ & p-value & Coefficient & S. E & $\begin{array}{c}\text { t- } \\
\text { Statistic }\end{array}$ & \multicolumn{1}{c|}{ p-value } \\
\hline C & 5.3725 & 2.0270 & 2.6504 & $0.0087 * * *$ & 6.0052 & 3.9020 & 2.5390 & $0.0 .0079 * * *$ \\
\hline CCC & -0.2690 & 0.4774 & -1.9420 & $0.0512 * *$ & -0.1502 & 0.3977 & -3.1236 & $0.0000^{* * *}$ \\
\hline FS & 0.0175 & 0.0131 & 1.3340 & 0.1838 & -0.2596 & 0.1803 & -1.9404 & $0.0914 *$ \\
\hline DR & -0.0271 & 0.0133 & -2.0463 & $0.0421 * *$ & -0.1423 & 0.0724 & -2.1055 & $0.0361 * *$ \\
\hline R-Squared & & 0.5751 & & R-Squared & 0.7322 & $\begin{array}{l}\text { Adjusted R- } \\
\text { Squared }\end{array}$ \\
\hline Adjusted R-Squared & & 0.5147 & & 0.5421 \\
\hline
\end{tabular}

Note: $[* * * * *$ and $*$ ] represents level of significance at $1 \%, 5 \%$ and $10 \%$, respectively. 